\title{
Short Communication: \\ Detection of lectin gene (MLL1 and M35) in mulberry plant (Morus spp.) from Bogor, West Java, Indonesia
}

\author{
YASINTA RATNA ESTI WULANDARI", YOGIARA, MICHAEL LIZAR \\ Department of Biology, Faculty of Biotechnology, Universitas Katholik Atma Jaya. J1. Jenderal Sudirman No. 51, South Jakarta 12930, Indonesia. Tel,: \\ +62 215703306, Fax.: +62-21-5708811."email: yasinta.ratna@atmajaya.ac.id
}

Manuscript received: 23 August 2018. Revision accepted: 24 November 2018

\begin{abstract}
Wulandari YRE, Yogiara, Lizar M. 2018. Short Communication: Detection of lectin gene (MLL1 and M35) in mulberry plant (Morus spp.) from Bogor, West Java, Indonesia Biodiversitas 19: 2381-2384. Plant species contains carbohydrate-binding protein known as lectin or agglutinin. Lectin binds to specific carbohydrates, such as monosaccharides or oligosaccharides and initiates agglutination process. Lectin plays an important role as plant defense, so that it can be used to prevent pest attacks. Mulberry leaf lectin 1 (MLL1) from young leaves of Morus alba can be used against phytopathogenic bacteria, Pseudomonas syringae pv. mori. Mannosebinding lectin (M35) was found on stems of M. nigra as protein storage. M35 is also produced on roots of M. alba and induced by mulberry stem cuttings. This research purpose was to isolate and analyze lectin gene expression (MLL1 and M35) in M. alba var. multicaulis, M. cathayana, M. bombycis var. lembang, and M. alba var. kanva-2 from Bogor, West Java, Indonesia. Different plant organ including leaves, stems, and roots were used as source of samples and analyze using Reverse Transcription Polymerase Chain Reaction (RT-PCR). Our results showed that all of MLL1 genes were expressed in young leaves, but not expressed in stems and roots of mulberry plant samples. The M35 gene was expressed in young leaves, stems, and roots of all mulberry plant samples. Reverse Transcription PCR of MLL1 gene exhibited a 350 bp DNA band, while M35 gene exhibited a 99 bp DNA band.
\end{abstract}

Keywords: 1-deoxynojirimycin, antiherbivory, mulberry, Morus, plant-defense, RT-PCR

\section{INTRODUCTION}

Mulberry (Morus spp.) is a shurb and distributed worldwide, from tropical to temperate regions. Mulberry is traditionally used in Chinese medicines as a pharmaceutical and known for its nutritional benefits. Mulberry fruits are rich in phenolic compound, including flavonoids, anthocyanin, and carotenoids while the leaves are rich in chlorogenic acid, polyphenolic acid, quercetin, and 1deoxynojirimycin (DNJ). The fruits can be consumed directly, while the leaves can be used as herbal tea for prevent diabetes. Mulberry leaves can also be used as feeds for ruminants because the leaves are digestible (Huang et al. 2013; Geniola 2016).

Mulberry is often associated with the development of sericulture industry. Sericulture is an agro-based industry and involves rearing of silkworms for the silk production. Mulberry silk comes from the silkworm, Bombyx mori Linnaeus. which solely feeds on the leaves of mulberry plant. Sericulture industry often disturbed by pest population. It causes extensive damage to host plants and fluctuation in cocoon production. The major insects orders known to be the pest of mulberry plant are Lepidoptera, Hemiptera, Coleoptera, Thysanoptera, Orthoptera, and Isoptera (Avhad and Hiware 2013). Pest populations can be managed by using chemical pesticides, but if used excessively can harm the plants itself, and other organisms as well. The high risk groups exposed to chemical pesticides includes production workers and agricultural farm workers. Pesticides also contaminate environment such as soil, air, and water (Aktar et al. 2009). Therefore, other compounds that can be used as a plant defense are needed so as to reduce the use of chemical pesticides.

Some studies have found that lectin content of plants can be used as antibacterial, antiinsecticidal, antiherbivory, and antifungal to prevent pest attacks (Peumans and Damme 1995). Lectin are carbohydrate-binding proteins present in most of the plants and in some animal. Lectin can be found at seeds, bulbs, leaves, stems, and roots of the plants. Mulberry leaf lectin 1 (MLL1) which is isolated from young leaves of $M$. alba. It has a specificity to $\mathrm{N}$ glycolylneuraminic acid (NeuGc) and against a specific phytopatogenic bacteria, Pseudomonas syringae pv. mori (Ratanapo et al. 1998, 2001). Other studies (Van Damme et al. 2002; Du et al. 2016) reported that mannose-binding lectin (M35) has a binding specificity to mannose that was found on stems and roots of Morus nigra or Black Mulberry. This study aimed to isolate and analyze lectin gene expression (MLL1 and M35) on different organ from the mulberry plant species using Reverse Transcription Polymerase Chain Reaction (RT-PCR) method.

\section{MATERIALS AND METHODS}

\section{Sample preparation}

A total of 10 mulberry stem cuttings from $M$. alba var. multicaulis, M. cathayana, M. bombycis var. lembang, and 
M. alba var. kanva-2 as the mother plant were taken from University Farm belong to Bogor Agricultural University (IPB) in Sukamantri, Bogor, West Java, Indonesia and grown in the green house of Faculty of Biotechnology, Atma Jaya Catholic University of Indonesia.

\section{RNA isolation}

Samples were taken and weighed as much as $100 \mathrm{mg}$ from young leaves, stems, and roots organ from different species of mulberry plants. Total RNA was isolated from these samplesusing GeneJET Plant RNA Purification Mini Kit (ThermoScientific, USA) following manufacture's protocol. The quality of isolated RNA was checked for by using agarose gel electrophoresis with $1 \%$ agarose concentration and run at 90 volt for $60 \mathrm{~min}$. The concentration and purity of RNA isolates were measured by using NanoDrop 2000 UV-Vis Spectrophotometer (ThermoScientific, USA).

\section{cDNA synthesis}

Synthesis of first strand cDNA was done by using RevertAid First Strand cDNA Synthesis Kit (ThermoScientific, USA). The cDNA synthesis was performed for all RNA samples and reference (GAPDH RNA). The reaction mixtures were incubated at $42{ }^{\circ} \mathrm{C}$ for $60 \mathrm{~min}$. The reaction was terminated by incubation at $70^{\circ} \mathrm{C}$ for $5 \mathrm{~min}$. The reaction product can be directly used for PCR or can be stored at a temperature of $-20^{\circ} \mathrm{C}$ at freezer, or it can be stored at a $-80{ }^{\circ} \mathrm{C}$ freezer. The cDNA synthesis were completed by mixing first strand cDNA with each of MLL1 and M35 primer pairs (Table 1), and KAPA2G Fast Ready Mix PCR Kit (KAPABiosystems, USA).

The optimum condition for PCR of MLL1 and M35 consisted of initial denaturation $94{ }^{\circ} \mathrm{C}, 5 \mathrm{~min}$; denaturation $94{ }^{\circ} \mathrm{C}, 30 \mathrm{sec}$; annealing $52^{\circ} \mathrm{C}, 1 \mathrm{~min}$ for MLL1 and $55^{\circ} \mathrm{C}$, $1 \mathrm{~min}$ for $\mathrm{M} 35$; extension $72^{\circ} \mathrm{C}, 1 \mathrm{~min}$; final extension 72 ${ }^{\circ} \mathrm{C}, 7 \mathrm{~min}$, and total 35 cycles. The cDNA synthesis was confirmed by amplification of GAPDH, 18S rRNA, and $r b c \mathrm{~L} .18 \mathrm{~S}$ rRNA and $r b c \mathrm{~L}$ genes were plant genes internal control. The condition PCR of GAPDH, 18S rRNA, and $r b c \mathrm{~L}$ were as follow: initial denaturation $94{ }^{\circ} \mathrm{C}, 5 \mathrm{~min}$; denaturation $94{ }^{\circ} \mathrm{C}, 30 \mathrm{sec}$; annealing $58{ }^{\circ} \mathrm{C}$, $30 \mathrm{sec}$ for GAPDH or $51{ }^{\circ} \mathrm{C}, 30 \mathrm{sec}$ for $18 \mathrm{~S}$ rRNA and $r b c \mathrm{~L}$; extension $72{ }^{\circ} \mathrm{C}, 2 \mathrm{~min}$; final extension $72{ }^{\circ} \mathrm{C}, 7 \mathrm{~min}$, and total 35 cycles.

Verification of the PCR products was performed using agarose gel electrophoresis with $2 \%$ agarose. Electrophoresis was run at 80 Volt for 90 min followed by $\mathrm{EtBr}$ staining for $30 \mathrm{~min}$ and destained in $\mathrm{ddH}_{2} \mathrm{O}$ for 10 min. The agarose gel is exposed to Ultraviolet (UV) light on the Gel Doc ${ }^{\text {TM }}$ EQ System (BioRad, US) for visualization.

\section{RESULTS AND DISCUSSION}

\section{RNA isolation}

RNA was isolated from roots sample were visualized by using agarose gel electrophoresis yielded two bands $28 \mathrm{~S}$ rRNA and 18S rRNA (Figure 1). The presence of these two bands indicates that RNA is isolated intact and can be used for first strand synthesis of cDNA.

Based on the results of the measurement of the quantity and purity of RNA can be seen that the young leaves organ might yield RNA concentration higher than stems and roots organ (Table 2).

\section{First strand synthesis of cDNA}

RNA isolates were synthesized into cDNA and verification of cDNA synthesis is amplified by $18 \mathrm{~S}$ rRNA and $r b c \mathrm{~L}$ primer. The cDNA amplification of samples with 18S rRNA (Figure 2) and $r b c \mathrm{~L}$ (Figure 3) primer as an internal control of plant RNA is done. All samples were successfully amplified by $18 \mathrm{~S}$ and $r c b \mathrm{~L}$ primer and produce a $500 \mathrm{bp}$ band. The results obtained are in accordance with the previous study that $r b c \mathrm{~L}$ gene is about 599 bp (Smit et al. 1999; Marghali et al. 2014).

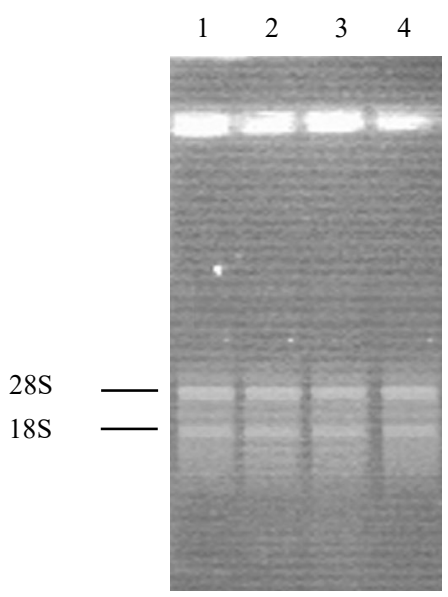

Figure 1. RNA isolation visualization results from roots of: 1. $M$. alba var. multicaulis, 2. M. cathayana, 3. M. bombycis var. lembang, 4. M. alba var. kanva-2

Table 2. RNA quantity and purity measurements

\begin{tabular}{lllll}
\hline Species & Organ & $\begin{array}{l}\text { [RNA] } \\
\text { ng/ } \mathbf{H L}\end{array}$ & $\mathbf{2 6 0 / 2 8 0}$ & $\mathbf{2 6 0 / 2 3 0}$ \\
\hline & & & & \\
M. alba var. & Leaves & 163.8 & 1.95 & 1.80 \\
multicaulis & Stems & 102 & 2.10 & 1.77 \\
& Roots & 50.8 & 2.01 & 1.65 \\
M. cathayana & Leaves & 246.8 & 1.87 & 2.00 \\
& Stems & 71.1 & 2.15 & 1.75 \\
M. bombycis var. & Roots & 96.3 & 2.02 & 1.67 \\
lembang & Leaves & 296.6 & 1.89 & 2.18 \\
& Stems & 158.2 & 2.00 & 1.81 \\
M. alba var. kanva-2 & Roots & 154.1 & 1.95 & 1.97 \\
& Leaves & 173.3 & 1.81 & 2.07 \\
& Stems & 78.4 & 2.11 & 1.71 \\
& Roots & 68.4 & 2.03 & 1.60 \\
\hline
\end{tabular}


Table 1. List of primer for cDNA synthesis

\begin{tabular}{lllcc}
\hline $\begin{array}{l}\text { Gene } \\
\text { name }\end{array}$ & $\begin{array}{l}\text { Genbank } \\
\text { accession } \\
\text { Number }\end{array}$ & Forward/reverse primer sequence (5'-3') & Size & Source \\
\hline MLL1 & JF745131.1 & $\begin{array}{l}\text { GG (A/C)GT (G/C)GC (A/C)TT }(\mathrm{C} / \mathrm{T}) \mathrm{GA}(\mathrm{C} / \mathrm{T}) \mathrm{G} \\
\text { A (C/T)GG / CCTTTGATCC }(\mathrm{A} / \mathrm{G})(\mathrm{A} / \mathrm{G}) \mathrm{C}(\mathrm{A} / \mathrm{G}) \mathrm{AT} \\
\text { (C/T) }(\mathrm{A} / \mathrm{T})(\mathrm{A} / \mathrm{T}) \mathrm{GC}\end{array}$ & $350 \mathrm{bp}$ & (Kankamol et al. 2012) \\
M35 & AAL10685.1 & $\begin{array}{l}\text { ATCCATAAGAGCAAGCA } \\
\text { CC / GTTGGCTGAGGATAGG TTC }\end{array}$ & 99 bp & (Du et al. 2016) \\
\hline
\end{tabular}

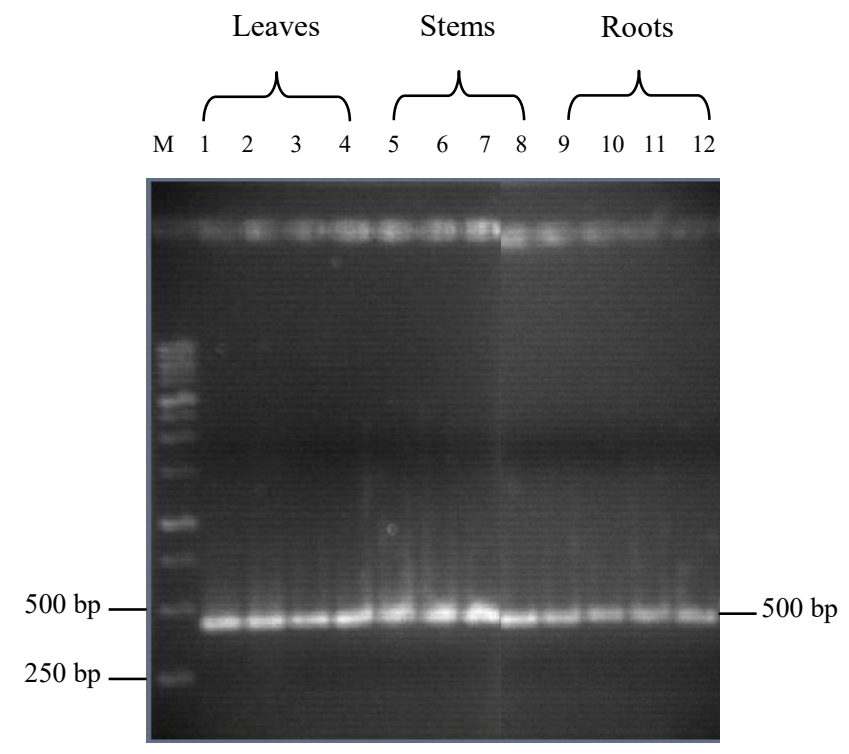

Figure 2. 18S rRNA gene visualization results. $1 \mathrm{~Kb}$ DNA ladder (M); cDNA sample from $M$. alba var. multicaulis $(1,5,9), M$. cathayana $(2,6,10), M$. bombycis var. lembang $(3,7,11)$, and $M$. alba var. kanva-2 $(4,8,12)$

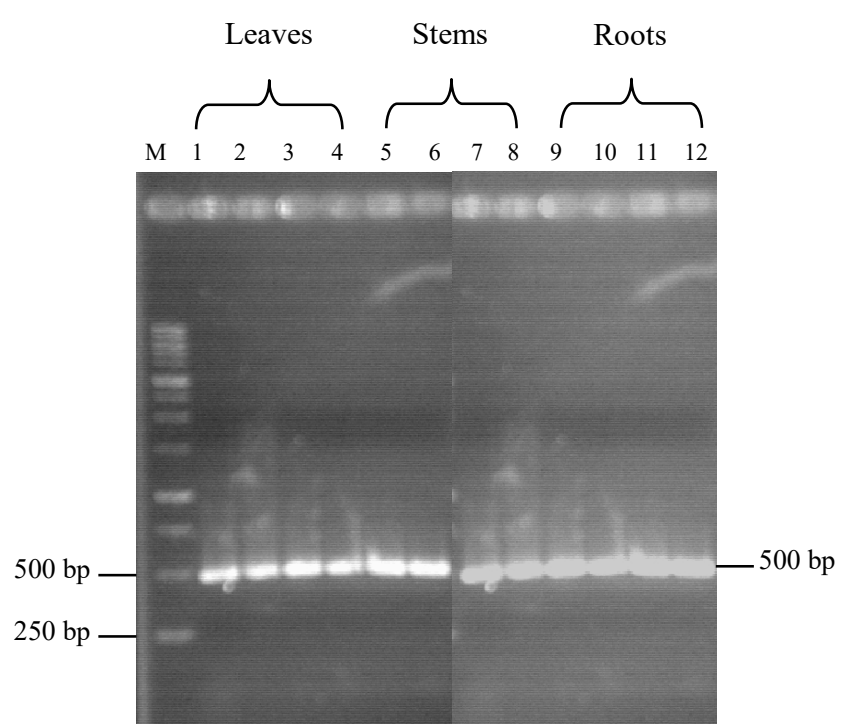

Figure 3. $r c b \mathrm{~L}$ gene visualization results. $1 \mathrm{~Kb}$ DNA ladder $(\mathrm{M})$; cDNA sample from $M$. alba var. multicaulis $(1,5,9), M$. cathayana $(2,6,10), M$. bombycis var. lembang $(3,7,11)$, and $M$. alba var. kanva-2 $(4,8,12)$

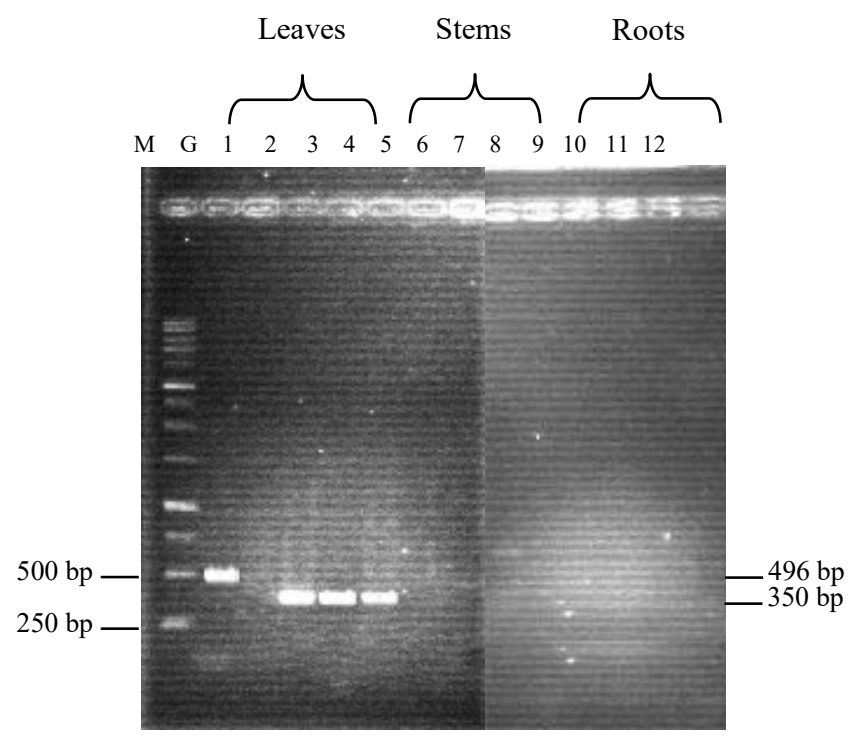

Figure 4. MLL1 gene visualization results. $1 \mathrm{~Kb}$ DNA ladder (M); GAPDH as the control kit (G); cDNA sample from $M$. alba var. multicaulis $(1,5,9)$, M. cathayana $(2,6,10)$, M. bombycis var. lembang $(3,7,11)$, and M. alba var. kanva-2 $(4,8,12)$

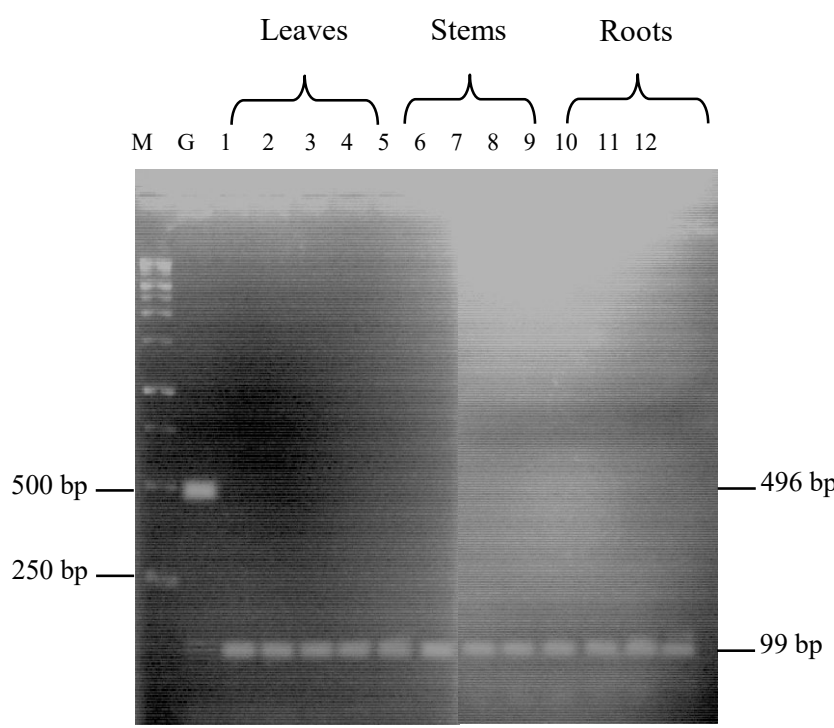

Figure 5. M35 gene visualization results. $1 \mathrm{~Kb}$ DNA ladder (M); GAPDH as the control kit (G); cDNA sample from $M$. alba var. multicaulis $(1,5,9)$, M. cathayana $(2,6,10)$, M. bombycis var. lembang $(3,7,11)$, and $M$. alba var. kanva-2 $(4,8,12)$ 


\section{cDNA amplification and verification}

cDNA amplification of lectine genes were done by using MLL1 (Figure 4) and M35 (Figure 5) primer as the gene target. All samples were successfully amplified by MLL1 primer and produce a $350 \mathrm{bp}$ band, while by M35 primer produce a 99 bp band.

cDNA of GAPDH were successfully amplified with MLL1 and M35 primer as shown by the appearance of a 496 bp DNA band of control and all samples. Young leaves samples from $M$. cathayana, M. bombycis var. lembang, and M. alba var. kanva-2 produced a 350 bp band. However, young leaves sample from $M$. alba var. multicaulis also stems and roots from $M$. alba var. multicaulis, M. cathayana, M. bombycis var. lembang, and M. alba var. kanva-2 with MLL1 primer did not show any bands. This indicated that cDNA samples can not be amplified using MLL1 primer because there was no match of cDNA samples with sequence of primer (Slack 2006). The results were similiar with the previous study that MLL1 gene size is 350 bp (Kankamol et al. 2012). In addition, all samples were successfully amplified with M35 primer and produce a $99 \mathrm{bp}$ band. This indicates all samples are compatible with the primer sequences so that they can be well amplified. The results obtained are in accordance with the literature that M35 gene size is $99 \mathrm{bp}$ (Du et al. 2016). This preliminary study successfully detected MLL1 and M35 gene through PCR amplification. To confirm that the amplicons were correctly belongs to MLL1 and M35, DNA sequencing should be performed.

Based on PCR detection method, we conclude that M35 and MLL1 gene were found in mulberry species from Bogor, West Java. MLL1 gene might be expressed on the young leaves organ of Morus cathayana, M. bombycis var. lembang, and M. alba var. kanva-2. However, MLL1 might not be expressed in young leaves of $M$. alba var. multicaulis, and in the stems and roots organ of all mulberry plant species. Meanwhile, M35 gene might not be expressed on the young leaves, stems, and roots organ in all mulberry plant species.

\section{ACKNOWLEDGEMENTS}

This research was financially supported by Faculty of Biotechnology, Atma Jaya Catholic University of Indonesia in 2016. We thank University Farm of Bogor Agricultural University in Sukamantri, Bogor, West Java for providing samples of mulberry plants for this research.

\section{REFERENCES}

Aktar MW, Sengupta D, Chowdury A. 2009. Impact of pesticides use in agriculture: their benefits and hazards. Interdiscip Toxicol 2 (1): 1-12.

Avhad SB, Hiware CJ. 2013. Mulberry defoliators: distribution and occurrence from Aurangabad (M.S.), India. J. Entomol. Zool. Stud. 1 (4): 1-6.

Du W, Ban Y, Nie H, Tang Z, Du X, Cheng J. 2016. A comparative transcriptome analysis leads to new insights into the molecular events governing root formation in mulberry softwood cuttings. Plant Mol. Biol. Report 34 (2): 365-373.

Geniola C. 2016. Identifikasi Senyawa 1-deoxynojirimycin pada Daun Morus alba var. multicaulis dan Morus bombycis var. lembang [Thesis]. Atma Jaya Catholic University of Indonesia, Jakarta. [Indonesian]

Huang HP, Ou TT, Wang CJ. 2013. Mulberry and its bioactive compounds, the chemoprevention effects and molecular mechanisms in vitro and in vivo. J Tradit. Complement Med. 3 (1): 7 15.

Kankamol C, Promboon A, Saksoong P, Ratanapo S. 2012. Characterization of Partial cDNA Clone Encoding Mulberry Leaf Lectin [Dissertation]. Kasetsart University, Bangkok. [Thailand]

Peumans WJ, Damme EJM. 1995. Lectin as plant defense proteins. Plant Physiol. 109 (2): 347-352.

Ratanapo S, Ngamjunyaporn W, Chulavatnatol M. 1998. Sialic acid binding lectins from leaf of mulberry (Morus alba). Plant Sci. 39 (2): 141-148.

Ratanapo S, Ngamjunyaporn W, Chulavatnatol M. 2001. Interaction of a mulberry leaf lectin with a phytopathogenic bacterium, $P$. syringae pv. mori. Plant Sci. 160 (4): 739-744.

Slack JMW. 2006. Essential Developmental Biology. $2^{\text {nd }}$ ed. Blackwell Publishing, Oxford.

Van Damme EJM, Hause B, Hu J, Baree A, Rouge P, Proost P, Peumans PJ. 2002. Two distinct jacalin-related lectins with a different specificity and subcellular location are major vegetative storage proteins in the bark of the black mulberry tree. Plant Physiol. 130 (2): 757-769. 